\title{
Cytotoxicity of synthesized 1,4-naphthoquinone analogues on selected human cancer cell lines
}

Navneet Kishore ${ }^{a}$, Brigitte Binneman ${ }^{\mathrm{a}}$, Anita Mahapatra ${ }^{\mathrm{a}, \mathrm{b}}$, Maryna van de Venter ${ }^{\mathrm{c}}$, Debbie du Plessis-Stoman ${ }^{\mathrm{c}}$, Gerhardt Boukes $^{\mathrm{c}}$, Peter Houghton ${ }^{\mathrm{a}, \mathrm{d}}$, J.J. Marion Meyer ${ }^{\mathrm{a}}$, Namrita Lall ${ }^{\mathrm{a}}$

${ }^{a}$ Department of Plant Science, Plant Sciences Complex, University of Pretoria, Pretoria-0002, South Africa

${ }^{b}$ Department of Natural Products, National Institute of Pharmaceutical Education and Research, Ahmedabad-380054, India

${ }^{c}$ Department of Biochemistry and Microbiology, Nelson Mandela Metropolitan University, Port Elizabeth, Summerstrand Campus, 6031, South Africa

${ }^{d}$ Pharmaceutical Sciences Division, Franklin-Wilkins Building, 150 Stamford Street, King's College London, London SE1 9NN, UK

* Corresponding Author. Tel.: +27-12-420-2524; fax: +27-12-420-6668; e-mail: namritaup14@gmail.com

\section{Graphical Abstract}

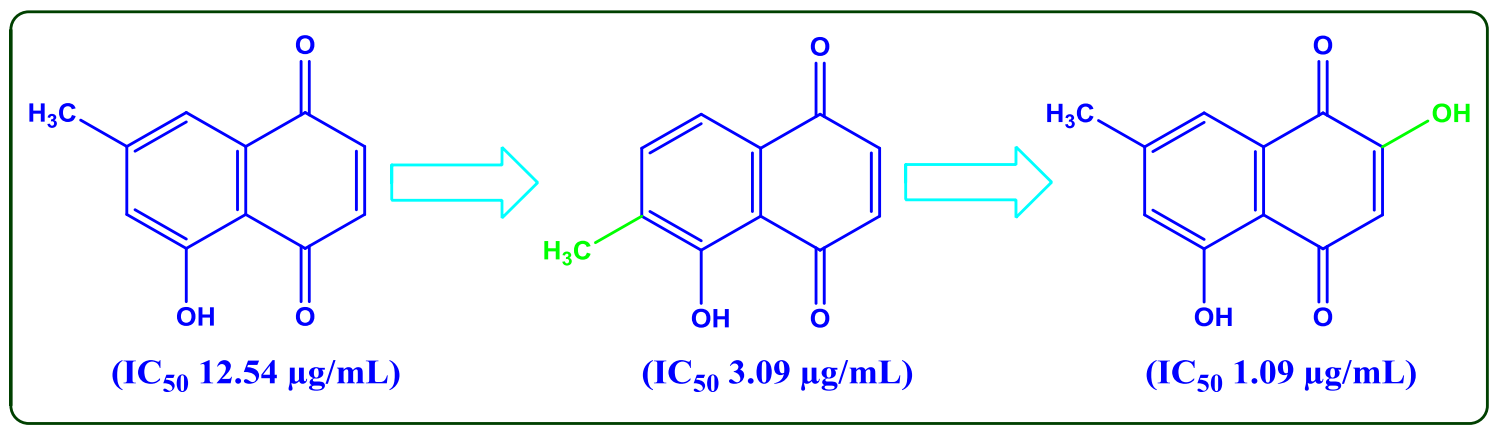

\begin{abstract}
In an effort to establish new candidates with enhanced anticancer activity of 5-hydroxy-7-methyl-1,4naphthoquinone scaffold (7-methyljuglone) previously isolated from the root extract of Euclea natalensis, a series of 7-methyljuglone derivatives have been synthesized and assessed for cytotoxicity on selected human cancer lines. These compounds were screened in vitro for anticancer activity on MCF-7, HeLa, SNO and DU145 human cancer cell lines by MTT assay. Most of them exhibited significant toxicity on cancer cell lines with lower $\mathrm{IC}_{50}$ values. The most potent derivative (19) exhibited the toxicity on HeLa and DU145 cell lines with IC 50 value of 5.3 and $6.8 \mu \mathrm{M}$ followed by compound (5) with $\mathrm{IC}_{50}$ value of 10.1 and $9.3 \mu \mathrm{M}$, respectively. Structureactivity relationship reveals that the fluoro substituents at position C-8 while hydroxyl substituents at C-2 and C5 positions played an important role in toxicity.
\end{abstract}

Keywords: Euclea natalensis, 7-Methyljuglone derivatives, Cytotoxicity, Cell cycle analysis, Cell apoptosis

\section{Introduction}

Quinone scaffolds are widespread in nature and present in many drugs which are used clinically in the therapy of solid cancer. The cytotoxic effects of these quinones are mainly due to the inhibition of DNA topoisomeraseII. ${ }^{1,2}$ Naphthoquinones are widely distributed in plants, fungi and some animals, and most of these are found to exhibit an interesting range of pharmacological properties. 1,4-Naphthoquinone is an important example of quinone family and is used as a raw material in pharmaceutical industries. 1,4-Naphthoquinone and its derivatives exhibited several interesting and different biological responses including antibacterial, ${ }^{3}$ antifungal, ${ }^{4,5}$ anti-inflammatory, antiplatelet, antiallergic, ${ }^{6}$ antithrombotic, ${ }^{7}$ antiviral, ${ }^{8}$ anticancer, $^{9-11}{ }^{1}$ apoptosis, ${ }^{12}$ lipoxygenase, ${ }^{13,14}$ radical scavenging ${ }^{15}$ and anti-ringworm ${ }^{16}$ activities. Recently, 1,4-Naphthoquinone derivatives were proved to be human DNA topoisomerase I and II inhibitors. ${ }^{2}$ The presence of two carbonyl groups in naphthoquinones that have the ability to accept one or two electrons to form the corresponding radical anion or di-anion species and their acid-base properties is responsible for the various biological activities. ${ }^{17,18}$ In another study, it was found that the presence of hydroxy groups at 5 and 8 positions, which facilitate the tautomerism in the structure of 1,4-naphthoquinone, reduced the electrophilicity of the naphthoquinone ring.

Cancer is the second leading cause of death worldwide despite a major endeavour of research and development in academia and pharmaceutical industry to search for new anticancer agents. ${ }^{19-21}$ Although major advances have been made by researchers but the medical need is still largely unmet due to many factors; among which are the lack of selectivity of conventional drugs leading to toxicity, the metastatic spreading, and multi- 
drug resistance. ${ }^{22-27}$ Novel and selective anticancer agents are urgently required due to problems associated with currently available anticancer drugs. The plant Euclea natalensis (A. DC.) is used traditionally for the treatment of cancer in South Africa. ${ }^{28,29}$ The metabolite 7-methyljuglone (7-MJ) previously isolated from this plant ${ }^{3}$, exhibited anticancer activity. A series of derivatives of 7-MJ were synthesized. Previous studies have shown that mono or dihydroxy substitution (at C-2 or C-5 and C-8 positions in the aromatic ring) of naphthoquinones resulted in higher toxicity as compared to the parent 1,4-naphthoquinone due to increased efficiency of redox cycling. ${ }^{3}$ The introduction of a fluorine atom into antibiotic quinolones has been shown to enhance their activity. In view of these previous observations, it was decided to synthesize 7-MJ derivatives in order to establish structure-activity relationship. This paper reports the synthesis and cytotoxicity of a series of 5-hydroxy-, 5alkoxy- and 5-acetoxy-8-substituted-naphthoquinones on selected human cancer cell lines. The mechanism of action was established by cell cycle analysis and structure activity relationship has also been discussed.

\section{Result and discussion}

\subsection{Synthesis of 1,4-naphthoquinone derivatives}

The synthesis of 7-MJ (1) and its derivatives 2-19 (Table 1) has been done by the same method that was previously used for the synthesis in our laboratory. ${ }^{3}$

\subsection{Cytotoxicity}

This is the first study that discloses the effects of 7-MJ derivatives on four cancer cell lines, cell cycle, apoptosis and caspase 3/7. To determine the fifty percent inhibitory concentration $\left(\mathrm{IC}_{50}\right)$ values of the compounds, the four adherent cancer cells were treated with several concentrations. All assays were carried out in triplicate. The cytotoxicity results (Table 1) revealed that most of the tested compounds exhibited good activity, mainly against prostate (DU-145), cervical (HeLa) and breast (MCF-7) cell lines while being less active against the oesophageal cancer cell line. Out of 18 derivatives, compounds 2-6 and 19 were found to be potent inhibitors of the growth of HeLa, DU-145 and MCF-7 cancer cell lines at very low concentrations.

The $\mathrm{IC}_{50}$ values showed (Table 1 ) that the compounds 2-15 and 19 exhibited very good anticancer activity against all the cell lines. The derivative 19 was the most significant one against cell lines (HeLa: $\mathrm{IC}_{50} 5.3 \mu \mathrm{M}$ and DU-145: $\mathrm{IC}_{50} 6.8 \mu \mathrm{M}$ ), followed by compounds 5 (DU-145: $\mathrm{IC}_{50} 9.3 \mu \mathrm{M}$ and SNO: $\mathrm{IC}_{50} 9.4 \mu \mathrm{M}$ ) and $\mathbf{4}(\mathrm{HeLa}$ : $\mathrm{IC}_{50} 10.2 \mu \mathrm{M}$ and DU-145: $\mathrm{IC}_{50} 15.4 \mu \mathrm{M}$ ); while the parent compound 1 (7-MJ) was found to be less active than most of the derivatives. The compound $\mathbf{5}$ also exhibited the toxicity against MCF-7 and HeLa cell lines with IC $_{50}$ values of 10.0 and $10.1 \mu \mathrm{M}$, respectively (Comparable to Cisplatin, IC ${ }_{50} 10.0 \mu \mathrm{M}$ ).

The introduction of a hydroxyl group at position C-2 in $\mathbf{1 9}$ resulted in a sixfold increase in the activity as compared to the parent compound $\mathbf{1}$. The presence of halogen substituent at C-8 also increased the activity. The cytotoxicity of $\mathbf{6}$ was found to be greater than $\mathbf{1}$; this clearly indicated that the change of position of $-\mathrm{CH}_{3}$ group from C-7 to C-6, enhanced the activity. The weak activity of derivatives 7-15 (5-Alkoxy or 5-Acetoxy) indicated that the presence of 5- hydroxyl group is necessary for the activity. When the carbonyl group of quinone was converted to acetate, the activity was reduced significantly. Hence, the weakest activity of the tetra-acetate derivatives 16-18 (1,2,4,5-tetraacetate) revealed that the quinone moiety is highly required for the development of new significant leads. Out of all the derivatives, on the basis of their activity, compounds 1-6 and 19 were taken up for further investigation.

\subsection{Cytotoxicity on human macrophages (U937) and peripheral blood mononuclear cells (PBMCs)}

Based on the cytotoxicity data of a few derivatives on most of the cell lines, compounds 1-6 and 19 were further tested on peripheral blood mononuclear cells (PBMCs) and on human macrophages. The comparative toxicity on PBMCs (Table 2, Fig. 1) suggested that compounds $\mathbf{4}$ and $\mathbf{1 9}$ were the least toxic, whilst the other compounds including 1 were found to be more toxic then the other derivatives at the lower concentrations tested. Compounds $4\left(\mathrm{IC}_{50}: 188.7 \mu \mathrm{M}\right)$ and $19\left(\mathrm{IC}_{50}: 54.0 \mu \mathrm{M}\right)$ were not toxic to the PBMCs, suggesting their actions to be specific for tumour cells in contrast to the other compounds tested in this study. The toxicity test on U937 cells (Fig. 2) revealed that the compounds $\mathbf{2 - 5}$ were the least toxic on U937 cells.

\subsection{Cell cycle analysis}

Based on the cytotoxicity data on PBMCs and U937 cells, compounds 2-6 and 19 were further tested for cell cycle analysis. The analysis demonstrated that these compounds, except for compound 19, caused an accumulation of cells in the $\mathrm{G}_{0} / \mathrm{G}_{1}$ phase and thus inhibited the transition of cells into $S$ phase. This was followed by increases in the proportion of cells in sub- $\mathrm{G}_{1}$ phase of the cell cycle. The major characteristics which have been used to assess apoptosis are the state and content of nuclear DNA. Apoptosis can be readily assessed by flow cytometric quantitation of red fluorescence from the fixed propidium iodide-stained, RNAse-treated cells. ${ }^{30}$ Apoptotic activity is heralded by sub-G $\mathrm{G}_{1}$ events on DNA histograms. ${ }^{31}$ To establish whether the tested compound inhibited cell growth by blocking cells in a certain phase of the cell cycle and/or induced apoptosis, cellular DNA was analysed ${ }^{32}$ and stained with PI and the cells were analyzed using flow cytometry. ${ }^{33}$ The cell cycle profile (Fig. 3) is represented through 3 independent experiments on U937 cell lines of compounds 2-6 and 19. A significant arrest at $G_{0} / G_{1}$ phase was observed both at 24 and $48 \mathrm{~h}$. Though in the $G_{0} / G_{1}$ and $S$ phases, cells did not proliferate significantly as compared to the control at $48 \mathrm{~h}$. They increased in sub- $\mathrm{G}_{1}$ phase (control: $1.5 \%$ 
and compounds 2-6: $10.9 \%-22.1 \%$ ). Therefore the compounds $\mathbf{2 - 6}$ and 19 arrested the cells in $\mathrm{G}_{0} / \mathrm{G}_{1}$ phase of the cell cycle.

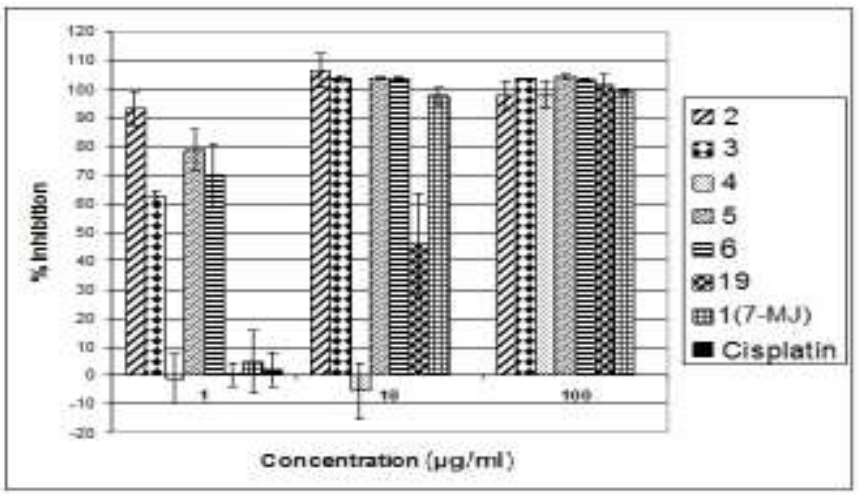

Figure 1. Percentage inhibition of Peripheral blood mononuclear cells (PBMCs) by highly active 7-MJ derivatives (Bars and error bars indicate mean \pm SD of quadruplicates).

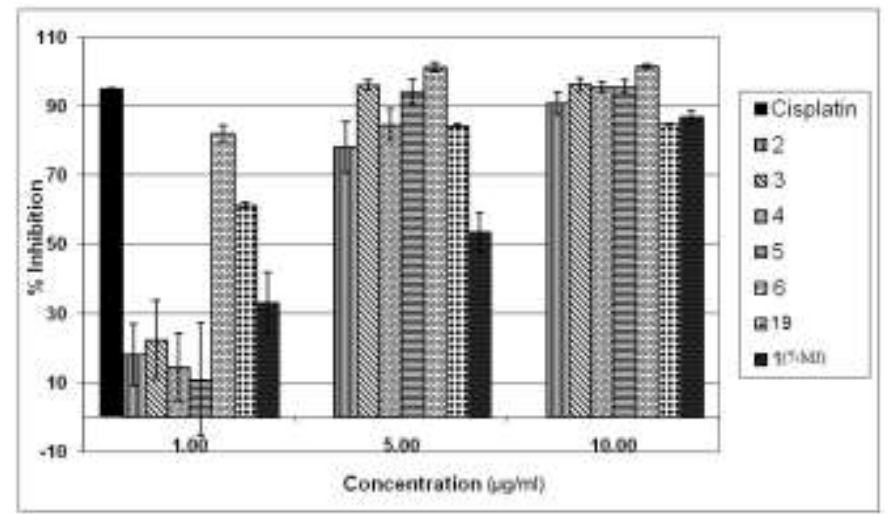

Figure 2. Percentage inhibition of U937 cells by selected derivatives (Bars and error bars indicate mean \pm SD of quadruplicates).

There was no increase in the number of apoptotic cells with cisplatin treatment after $12 \mathrm{~h}$, but there was an increase in the $\mathrm{G}_{0} / \mathrm{G}_{1}$ phase from $38.0 \%$ to $56.0 \%$, and hence a delay in the cell cycle in this phase. Previous reports showed that cisplatin induced a transient $\mathrm{G}_{1}$ arrest, $\mathrm{S}$ phase block and up regulation of p53 and p21 $1^{\text {WAFI/CTP1 }}$ expression in HepG2, but not HEP3B cells. ${ }^{34}$ It might be that either cisplatin delays the cell cycle late in the $\mathrm{G}_{0} / \mathrm{G}_{1}$ phase or early in the $S$ phase and as a result there is an overlap between the two phases and therefore a delay in the $\mathrm{G}_{0} / \mathrm{G}_{1}$ phase. At $48 \mathrm{~h}$ cisplatin showed an increase in the number of apoptotic cells.

The lower percentages found at all the other phases of the cell cycle were expected because of the increase in the $\mathrm{G}_{0} / \mathrm{G}_{1}$ phase. This means that, due to the delay in the $\mathrm{G}_{0} / \mathrm{G}_{1}$ phase (or early $\mathrm{S}$ phase), apoptosis was induced and the cells did not continue further with the cell cycle. Interestingly, $\beta$-hydroxyisovaleryl shikonin ( $\beta$-HIVS) has been reported to arrest cell cycle at $\mathrm{G}_{0} / \mathrm{G}_{1}$ phase by suppressing anti-apoptotic proteins. ${ }^{35} \mathrm{~A}$ small increase in the percentage of apoptotic cells by derivatives $\mathbf{2}$ and $\mathbf{5}$ at $24 \mathrm{~h}$ in sub-G $\mathrm{G}_{1}$ phase, suggested an early induction of apoptosis, which was confirmed by the results at $48 \mathrm{~h}$. At 24 and $48 \mathrm{~h}$ there was an increase in the percentage cells in the $\mathrm{G}_{0} / \mathrm{G}_{1}$ phase and decrease in all other cell cycle phases, which was expected. With the delay at the $\mathrm{G}_{0} / \mathrm{G}_{1}$ phase, the cells could follow through to the other phases of the cell cycle and therefore became apoptotic.

No increase in the percentage of apoptotic cells in sub- $G_{1}$ phase but an increase in the $G_{0} / G_{1}$ phase by derivatives 3 and 4 at $24 \mathrm{~h}$ indicated cell cycle arrest which could potentially lead to apoptosis. This was confirmed at $48 \mathrm{~h}$, when both showed increases in the percentage of $\mathrm{Sub}-\mathrm{G}_{1}$, from $2 \%$ to $18 \%$ and $2 \%$ to $16 \%$, respectively. Again there were delays for both compounds at the $\mathrm{G}_{0} / \mathrm{G}_{1}$ phase and as a consequence, a decrease in all the other phases because these cells could not continue through the cell cycle and therefore became apoptotic.

Of all the tested derivatives, $\mathbf{6}$ appeared to be the best. It does not delay the cell cycle and might be using another mechanism to induce apoptosis. A much lower number of apoptotic cells by compound 19 at 24 and $48 \mathrm{~h}$ suggested that it induced necrosis rather than apoptosis to kill the cells, even at an early stage, which could lead to inflammation. Hence the results would have to be confirmed using another method of apoptosis detection. All the tested compounds, except compound 19, showed an increase in apoptosis at $48 \mathrm{~h}$, and caused a delay at the $\mathrm{G}_{0} / \mathrm{G}_{1}$ phase. 
Table 1: List of synthesized 1,4-naphthoquinone derivatives and their cytotoxicity against human cancer cell lines
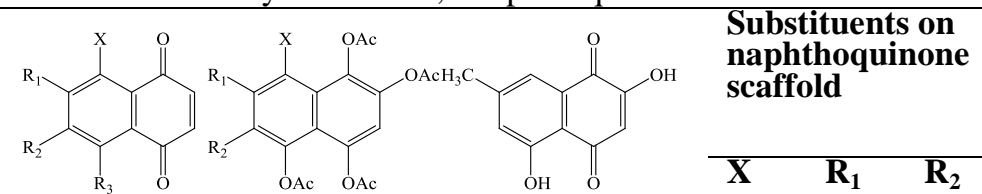

Cytotoxicity of derivatives on

scaffold

selected cancer cell lines

$\left(\mathrm{IC}_{50}{ }^{\mathrm{e}}\right.$ values are given in $\left.\mu \mathrm{M}\right)$

1-15

16-18

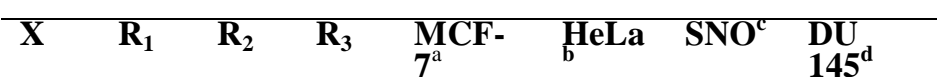

19

\begin{tabular}{|c|c|c|c|c|c|c|c|c|}
\hline $\begin{array}{l}\text { 5-Hydroxy-7-methyl-1,4-naphthoquinone (7- } \\
\text { MJ) (1) }\end{array}$ & $\mathrm{H}$ & $\mathrm{Me}$ & $\mathrm{H}$ & $\mathrm{OH}$ & 27.2 & 66.6 & 81.4 & 11.9 \\
\hline $\begin{array}{l}\text { 8-Chloro-5-hydroxy-7-methyl-1,4- } \\
\text { naphthoquinone (2) }\end{array}$ & $\mathrm{Cl}$ & $\mathrm{Me}$ & $\mathrm{H}$ & $\mathrm{OH}$ & 15.7 & 13.5 & 17.2 & 29.5 \\
\hline $\begin{array}{l}\text { 8-Bromo-5-hydroxy-7-methyl-1,4- } \\
\text { naphthoquinone (3) }\end{array}$ & $\mathrm{Br}$ & $\mathrm{Me}$ & $\mathrm{H}$ & $\mathrm{OH}$ & 15.5 & 11.3 & 14.9 & 46.3 \\
\hline $\begin{array}{l}\text { 8-Fluoro-5-hydroxy-7-methyl-1,4- } \\
\text { naphthoquinone (4) }\end{array}$ & $\mathrm{F}$ & $\mathrm{Me}$ & $\mathrm{H}$ & $\mathrm{OH}$ & 20.3 & 10.2 & 18.9 & 15.4 \\
\hline $\begin{array}{l}\text { 8-Chloro-5-hydroxy-6-methyl-1,4- } \\
\text { naphthoquinone (5) }\end{array}$ & $\mathrm{Cl}$ & $\mathrm{H}$ & $\mathrm{Me}$ & $\mathrm{OH}$ & 10.0 & 10.1 & 9.4 & 9.3 \\
\hline 5-Hydroxy-6-methyl-1,4-naphthoquinone (6) & $\mathrm{H}$ & $\mathrm{H}$ & $\mathrm{Me}$ & $\mathrm{OH}$ & 15.3 & 16.4 & 19.0 & 15.4 \\
\hline $\begin{array}{l}\text { 8-Chloro-5-methoxy-7-methyl-1,4- } \\
\text { naphthoquinone (7) }\end{array}$ & $\mathrm{Cl}$ & $\mathrm{Me}$ & $\mathrm{H}$ & $\mathrm{e}^{\mathrm{OM}}$ & 20.6 & 19.1 & 24.6 & 26.6 \\
\hline $\begin{array}{l}\text { 8-Chloro-5-ethoxy-7-methyl-1,4- } \\
\text { naphthoquinone (8) }\end{array}$ & $\mathrm{Cl}$ & $\mathrm{Me}$ & $\mathrm{H}$ & OEt & 40.0 & 19.0 & 44.2 & 25.4 \\
\hline $\begin{array}{l}\text { 5-Acetoxy-8-chloro-7-methyl-1,4- } \\
\text { naphthoquinone (9) }\end{array}$ & $\mathrm{Cl}$ & $\mathrm{Me}$ & $\mathrm{H}$ & $\begin{array}{l}\mathrm{OA} \\
\mathrm{c}\end{array}$ & 37.9 & 26.2 & 28.8 & 25.5 \\
\hline 5-Acetoxy-7-methyl-1,4-naphthoquinone (10) & $\mathrm{H}$ & $\mathrm{Me}$ & $\mathrm{H}$ & $\begin{array}{l}\mathrm{OA} \\
\mathrm{c}\end{array}$ & 14.7 & 17.2 & 28.1 & 24.1 \\
\hline 5-Methoxy-7-methyl-1,4-naphthoquinone (11) & $\mathrm{H}$ & $\mathrm{Me}$ & $\mathrm{H}$ & $\begin{array}{l}\mathrm{OM} \\
\mathrm{e}\end{array}$ & 15.3 & 21.1 & 22.5 & 30.7 \\
\hline 5-Ethoxy-7-methyl-1,4-naphthoquinone (12) & $\mathrm{H}$ & $\mathrm{Me}$ & $\mathrm{H}$ & OEt & 23.7 & 29.7 & 25.3 & 15.0 \\
\hline $\begin{array}{l}\text { 8-Chloro-5-methoxy-6-methyl-1,4- } \\
\text { naphthoquinone (13) }\end{array}$ & $\mathrm{Cl}$ & $\mathrm{H}$ & $\mathrm{Me}$ & $\mathrm{e}^{\mathrm{OM}}$ & 16.2 & 41.5 & 44.9 & 36.5 \\
\hline $\begin{array}{l}\text { 8-Chloro-5-ethoxy-6-methyl-1,4- } \\
\text { naphthoquinone (14) }\end{array}$ & $\mathrm{Cl}$ & $\mathrm{H}$ & $\mathrm{Me}$ & OEt & 32.2 & 33.2 & 37.3 & 26.2 \\
\hline $\begin{array}{l}\text { 5-Acetoxy-8-chloro-6-methyl-1,4- } \\
\text { naphthoquinone (15) }\end{array}$ & $\mathrm{Cl}$ & $\mathrm{H}$ & $\mathrm{Me}$ & $\begin{array}{l}\mathrm{OA} \\
\mathrm{c}\end{array}$ & 18.7 & 21.8 & 28.6 & 12.5 \\
\hline $\begin{array}{l}\text { 8-Chloro-7-methylnaphthalene-1,2,4,5-tetra-O- } \\
\text { acetate (16) }\end{array}$ & $\mathrm{Cl}$ & $\mathrm{Me}$ & $\mathrm{H}$ & - & 51.1 & 52.9 & 56.9 & 59.6 \\
\hline $\begin{array}{l}\text { 7-Methylnaphthalene-1,2,4,5-tetra-O-acetate } \\
\text { (17) }\end{array}$ & $\mathrm{H}$ & $\mathrm{Me}$ & $\mathrm{H}$ & - & 82.0 & 22.4 & 25.0 & 64.6 \\
\hline $\begin{array}{l}\text { 8-Chloro-6-methylnaphthalene-1,2,4,5-tetra-O- } \\
\text { acetate (18) }\end{array}$ & $\mathrm{Cl}$ & $\mathrm{H}$ & $\mathrm{Me}$ & - & 57.5 & 27.9 & 53.5 & 81.6 \\
\hline $\begin{array}{l}\text { 2,5-Dihydroxy-7-methyl-1,4-naphthoquinone } \\
\text { (19) }\end{array}$ & - & - & - & - & 14.6 & 5.3 & 23.2 & 6.8 \\
\hline Doxorubicin & - & - & - & - & 0.66 & 0.01 & 0.01 & 0.01 \\
\hline Cisplatin & - & - & - & - & 10.0 & 10.0 & - & - \\
\hline
\end{tabular}

(a) MCF-7- Breast adenocarcinoma; (b) HeLa- Cervical

epithelial carcinoma; (c) SNO - Oesophageal carcinoma; (d)

DU145- Prostate epithelial carcinoma; (e) $\mathrm{IC}_{50}$ - fifty percent

inhibitory concentration 

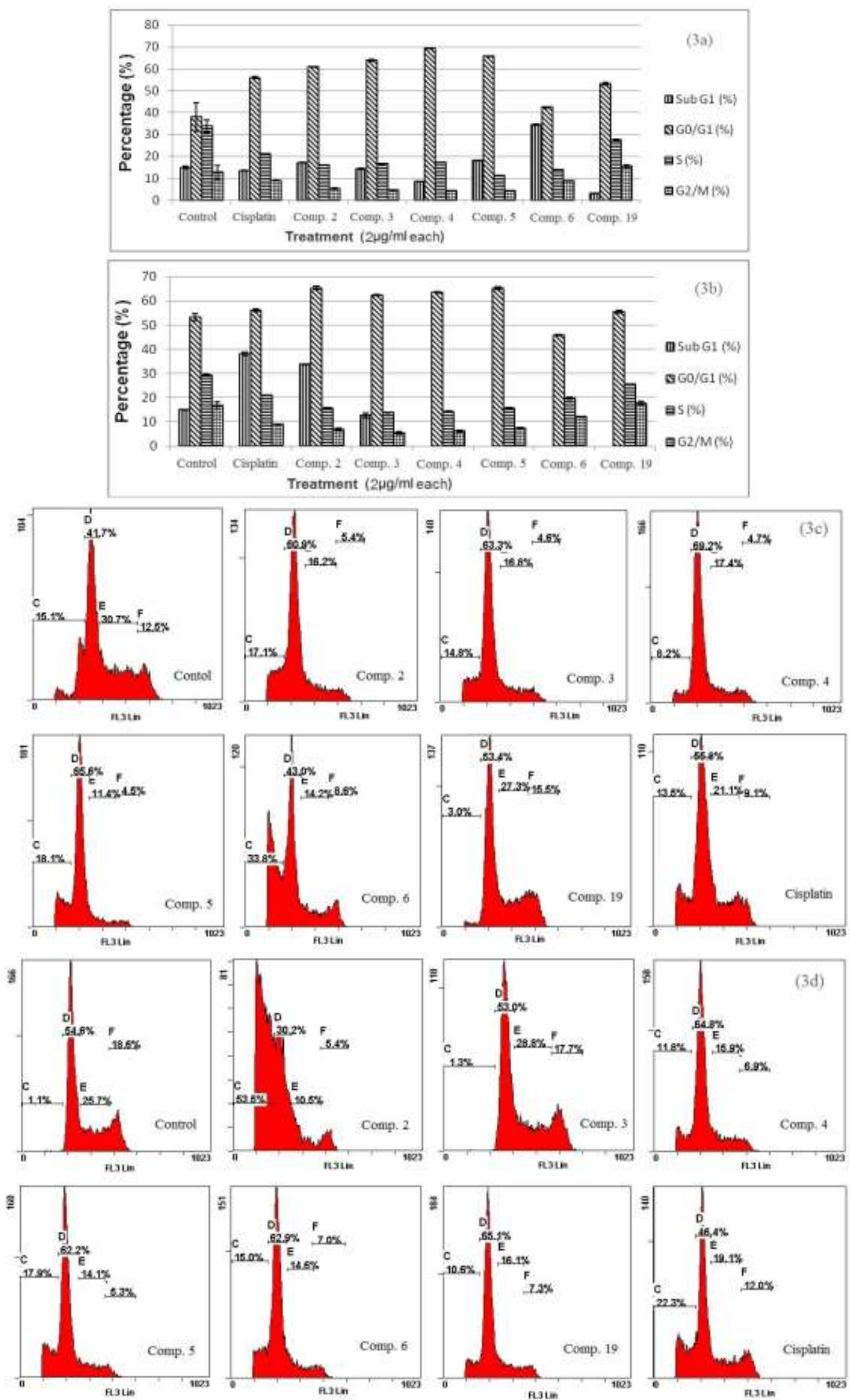

Figure 3. Effect of compounds on the cell cycle progression at different phases of U937 cell line after (3a \& $\mathbf{3 b})$ The cell cycle profile is representative of three independent experiments at 24 and 48 h, (3c \& 3d) Percentage of cells in different phases; Results represent mean \pm SEM of three independent experiments. 

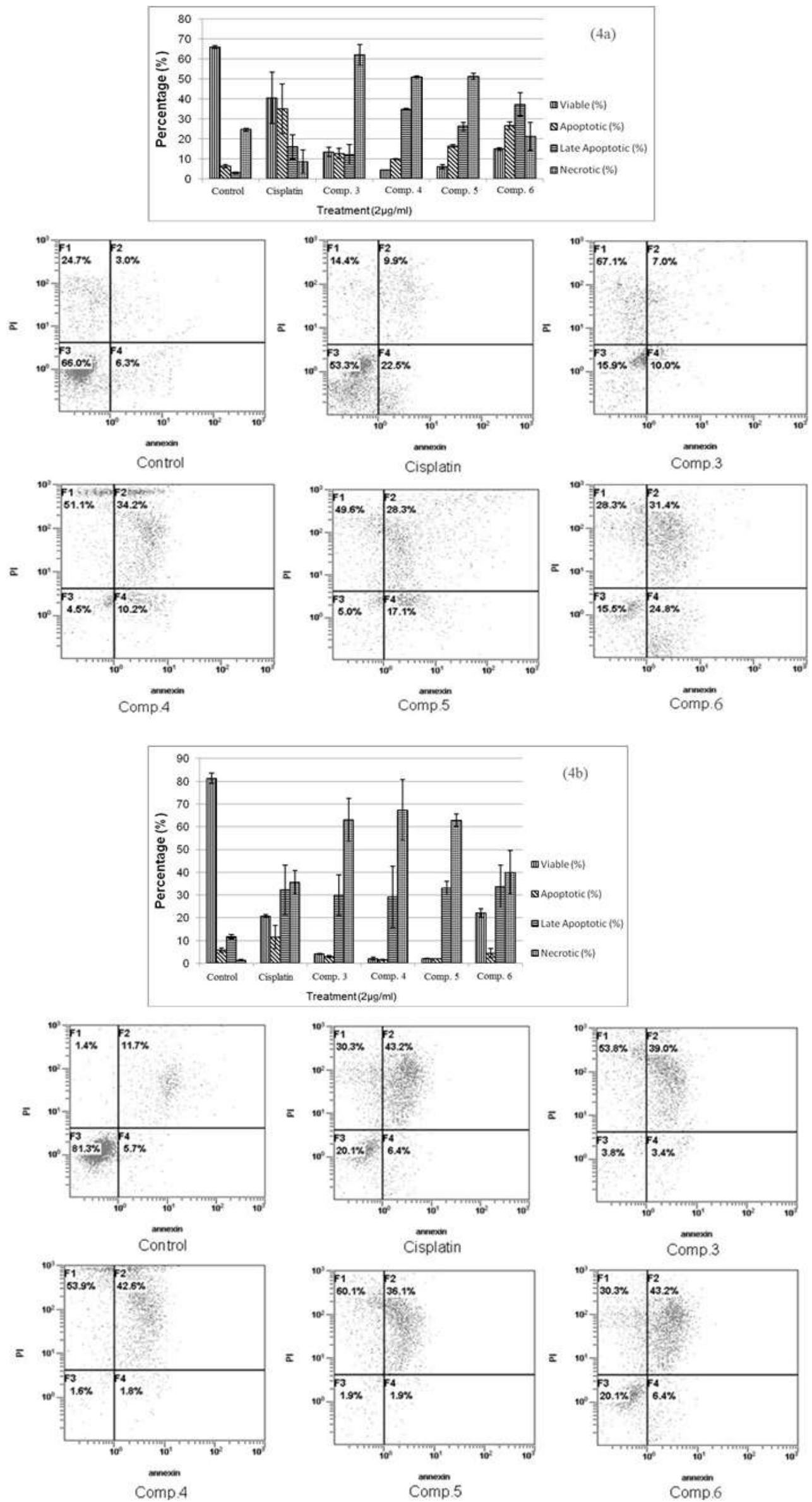

Figure 4: Apoptosis analysis of U937 cells exposed for $24 \mathrm{~h}(\mathbf{4 a})$ and $48 \mathrm{~h}(\mathbf{4 b})$. Double staining was used to distinguish between viable, early apoptotic, late apoptotic and necrotic cells. The lower left quadrant shows the viable Analysis of apoptosis 
Table 2: Cytotoxicity of compounds 1, 4 and 19 on peripheral blood mononuclear cells

\begin{tabular}{ll}
\hline Compound & $\mathbf{I C}_{\mathbf{5 0}}(\boldsymbol{\mu M})$ \\
\hline 1 & 18.4 \\
4 & 188.7 \\
19 & 54 \\
\hline
\end{tabular}

\subsection{Analysis of apoptosis}

On the basis of cell cycle analysis results, compounds 3-6 were further tested for apoptosis. The result (Fig. 4) showed that, the tested derivatives induced more apoptosis at $24 \mathrm{~h}$ (early apoptosis) as compared to $48 \mathrm{~h}$ (late apoptosis). There is significant difference in the proportions of non-apoptotic cells, and those in early and late apoptosis of cell treated were observed after 24 and $48 \mathrm{~h}$ of treatment with the derivatives when compared to the control. The sub- $\mathrm{G}_{1}$ peak from cell cycle analysis is a convenient tool for getting an indication of apoptosis.

Based on Annexin V/propidium iodide staining, $\mathbf{6}$ was found to be induce the greatest amount of apoptosis at an early apoptotic stage, which further supported the results of cell cycle with highest percentage cells in the sub-G phase in U937 cells. Compounds 3-5 induced apoptosis significantly in the late apoptotic quadrant after $24 \mathrm{~h}$, suggesting that apoptosis occurred very soon after exposure and shorter incubation time may have been better. This is supported by the very low percentage of viable cells seen after only $24 \mathrm{~h}$. The compounds 2-5 and 19 significantly inhibited the growth of HeLa and DU-145 cells in vitro, possibly by either down-regulation of antiapoptotic Bcl- $\mathrm{X}_{\mathrm{L}}$ and up-regulation of proapoptotic Bax or by increasing the p21 wat1/cip1 protein, which is involved in cell cycle arrest in $\mathrm{G}_{1}$ or $\mathrm{G}_{2}$ phase. ${ }^{36}$ Copeland et al. has reported that 2,3-dichloro-5,8-dimethoxy-1,4-naphthoquinone exhibits cytoxicity on androgen-dependent and -independent prostate cancer cell lines inducing apoptosis by arresting cell cycle at $\mathrm{G}_{1}$ phase. ${ }^{37}$ The cell cycle alterations indicate that cell cycle arrest is one of the primary mechanisms responsible for the anticancer activity of synthesized 7-MJ derivatives in HeLa and DU-145 cells.

\subsection{Caspase $3 / 7$ activity}

Based on the cell cycle analysis, compounds 4, 6 and 19 were further tested for induction of apoptosis. The induction of apoptosis was confirmed by induction of caspases. It is clear from table 3 that after incubation cisplatin and compound 19 activated caspase 3/7 activity by $6.6 \%$ and 7.4\%, respectively, while compounds 4 and 6 (Fig. 5) inhibited caspase $3 / 7$ activity by $-4.1 \%$ and $-3.2 \%$, respectively. No activation of caspase 3/7 by compounds 4 and 6 suggests that they induce apoptosis through a different pathway. Surprisingly, compound 19 activated caspase 3/7, although no apoptosis was seen during cell cycle analysis. It is possible that the induction and execution of apoptosis by 19 is slower than the other compounds (may be more time is required for inducing apoptosis). The increase in $\mathrm{G}_{0} / \mathrm{G}_{1}$ observed at $24 \mathrm{~h}$ from $38.0 \%$ to $53.1 \%$ might be the first indication of cell cycle arrest that could lead to apoptosis induction.

Table 3. Activation (\%) of Caspase $3 / 7$

\begin{tabular}{cl}
\hline Compounds & $\begin{array}{l}\text { Caspase } 3 / 7 \text { activity (\% above } \\
\text { control) }\end{array}$ \\
\hline Cisplatin & 5.89 \\
Compound $\mathbf{4}$ & -5.21 \\
Compound $\mathbf{6}$ & -5.14 \\
Compound $\mathbf{1 9}$ & 7.39 \\
\hline
\end{tabular}

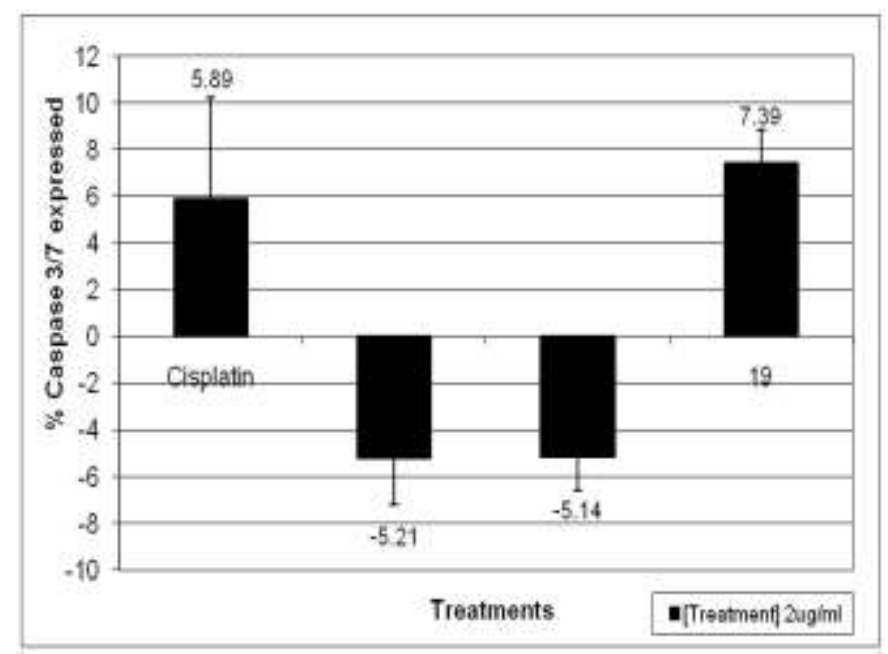

Figure 5. Activation (\%) of caspase 3/7. 


\section{Conclusions}

The compounds, 2,5-dihydroxy-7-methyl-1,4-naphthoquinone (19), 8-Chloro-5-hydroxy-6-methyl-1,4naphthoquinone (5), 8-fluoro-5-hydroxy-7-methyl-1,4-naphthoquinone (4) and 5-hydroxy-6-methyl-1,4-naphthoquinone (6) were found to be more cytotoxic and specific against human cervical epithelial carcinoma (HeLa), prostate epithelial carcinoma (DU-145) and breast adenocarcinoma (MCF-7) cancer cell lines as confirmed in cell cycle, apoptosis and caspase 3/7 activation as compared to the other derivatives. The derivative 2,5-dihydroxy-7methyl-1,4-naphthoquinone (19) was found to be the most potent among all; though not inducing apoptosis up to 48 $\mathrm{h}$ suggested that may be slow induction occurred, which had to be tested for longer time. The derivative $\mathbf{5}$ (8-Chloro5-hydroxy-6-methyl-1,4-naphthoquinone) and 6 (5-hydroxy-6-methyl-1,4-naphtho-quinone) could be further modified to reduce the toxicity.

\section{Material and methods}

\subsection{Cell culture}

Four human cancer cell lines, breast adenocarcinoma (MCF-7), cervical epithelial carcinoma (HeLa), oesophageal carcinoma (SNO) and prostate epithelial carcinoma (DU-145) (Highveld Biological, SA ) were maintained in culture flasks in complete Minimum Essential Medium, Eagle supplemented with $10 \%$ fetal bovine serum (Highveld Biological, SA), in a humidified $5 \% \mathrm{CO}_{2}$ incubator at $37^{\circ} \mathrm{C}$. Upon reaching confluence, the cells were trypsinized ( $0.25 \%$ trypsin containing $0.01 \%$ EDTA) for $10 \mathrm{~min}$ at $37{ }^{\circ} \mathrm{C}$ and then stopped by the addition of complete medium. About $1 \times 10^{5}$ of the viable cells were then re-suspended in complete medium. U937 cells were maintained in culture flasks in complete RPMI 1640 medium (Sigma, Germany) supplemented with 10\% fetal bovine serum (Delta Bioproducts, SA), containing $25 \mathrm{mM}$ HEPES and $2 \mathrm{mM}$ glutamine, in a humidified $5 \% \mathrm{CO}_{2}$ incubator at $37^{\circ} \mathrm{C}$.

\subsection{Cytotoxicity assay}

Cytotoxicity of the adherent cells was measured by the XTT (Sodium 3'-[1-(phenyl amino-carbonyl)-3,4tetrazolium]-bis-[4-methoxy-6-nitro) benzene sulfonic acid hydrate) method using the Cell Proliferation Kit II (Roche Diagnostics $\mathrm{GmbH})$. The cancer cells $(100 \mu \mathrm{l})$ were seeded at $1 \times 10^{5}$ per ml onto a microtiter plate and incubated for $24 \mathrm{~h}$ to allow the cells to attach to the bottom of the plate. A dilution series was made for the compounds $(0.1-100 \mu \mathrm{g} / \mathrm{ml})$, which was added to the microtiter plate and incubated for $48 \mathrm{~h}$. The XTT reagent was added to a final concentration of $0.3 \mathrm{mg} / \mathrm{ml}$ and incubated for 1-2 h. After incubation the absorbance of the colour complex was quantified at $490 \mathrm{~nm}$ using an ELISA plate reader with a reference wavelength set at $690 \mathrm{~nm}$. The $50 \%$ cell survival $\left(\mathrm{IC}_{50}\right)$ was analysed by using GraphPad Prism (version 4) from the concentration-effect relationship.

\subsection{Peripheral blood mononuclear cells (PBMCs)}

Blood was obtained from healthy adult volunteers. PBMCs were separated with BD Vacutainer ${ }^{\mathrm{TM}} \mathrm{CPT}^{\mathrm{TM}}$ cell preparation tubes containing sodium heparin. The method was followed as published ${ }^{38}$ but with different final concentrations tested $(1,10$ and $100 \mu \mathrm{g} / \mathrm{ml})$ using a fluorescence read at $560_{\mathrm{Ex}} / 590_{\mathrm{Em}}$ using a Fluoroskan Ascent FL fluorometer (ThermoLabsystems, Finland).

\subsection{Cell cycle analysis}

Compounds with the lowest $\mathrm{IC}_{50}$ values were further investigated for the mechanism of action. U937 cells were seeded in complete RPMI 1640 medium at a density of $2 \times 10^{6}$ cells per millilitre in flasks. After a recovery period of $24 \mathrm{~h}$, the selected compounds (1-6) were dissolved in DMSO $(2 \mu \mathrm{g} / \mathrm{ml})$ and added to the cells. Cisplatin $(10 \mu \mathrm{M})$ was added as positive control and DMSO as negative control. The flasks were further incubated for $24 \mathrm{~h}$. The Coulter ${ }^{\circledR}$ DNA Prep ${ }_{38}^{\mathrm{TM}}$ Reagents Kit (Beckman Coulter) was prepared as per kit instructions and the method was followed as published, ${ }^{38}$ with the difference of $500 \mu \mathrm{l}$ lysis buffer added and $1 \mathrm{ml}$ of propidium iodide (PI) added. The cells were analysed on a Beckman-Coulter FC500 Flow Cytometer (Miami, FL, USA). The respective software was used for the acquisition and analysis of data and the percentage of cells in each phase was determined in the gated population of singlet cells.

\subsection{Analysis of apoptosis}

The cell suspensions prepared for the cell cycle analysis were used for the annexin V-FITC/PI staining. Reagents of the Annexin V-FITC Kit (Beckman Coulter) were prepared as per kit instructions and kept on ice until further use. The reported method ${ }^{38}$ was followed, the samples were analysed on a Beckman Coulter FC500 flow cytometer (Miami, FL, USA).

\subsection{Caspase $3 / 7$ activity assay}

The Caspase 3/7 detection kit (Biomol) was used and the reagents were prepared as described in the kit. To evaluate caspase 3 activities, the U937 cells and compounds were prepared for the cell cycle analysis experiments. The compounds were added to the cells and control prepared and incubated for $24 \mathrm{~h}$. The flasks were mixed gently by hand so that the cells mixed well since they tend to settle while standing. $2.0 \mathrm{~mL}$ of RPMI 1640 medium containing cells and compounds, positive control, and negative control was removed from each flask and transferred into separate $2 \mathrm{~mL}$ Eppendorf tubes. The Eppendorf tubes were centrifuged and $290 \mu \mathrm{l}$ of RPMI 1640 medium was added and the cell suspension was transferred to a black microtiter plate. At least $2 \times 10^{5}$ cells per $100 \mu 1$ aliquot was added per well. Ten microlitres of the 30x CR (DEVD) $)_{2}$ working solution was added to the $290 \mu$ treated cells and 
mixed gently by taking in and expelling the cells with a pipette. The black microtiter plate was wrapped in foil and incubated for $2 \mathrm{~h}$ at $37^{\circ} \mathrm{C}$ under $5 \% \mathrm{CO}_{2}$. The cells tend to settle and were gently re-suspended every 20 minutes to ensure that the CR (DEVD) 2 was evenly dispersed among all the cells. The plates were read with ThermoLabsystem Fluoroskan AscentFL fluorescence reader at the wavelengths of 544:620 nm and 544:590 nm.

\section{Acknowledgments}

The authors thank University of Pretoria and National Research Foundation (NRF) for the financial grants.

\section{References}

1. Leopold, W. R.; Shillis, J. L.; Mertus, A. E.; Nelson, J. M.; Roberts, B. J.; Jackson, R. C. Cancer Res. $1984,44,1928$.

2. Fujii, N.; Yamashita, Y.; Arima, Y.; Nagashima, M.; Nakano, H. Antimicrob. Agents Chemother. 1992, $36,2589$.

3. Mahapatra, A.; Mativandlela, S. P. N.; Binneman, B.; Fourie, P. B.; Hamilton, C. J.; Meyer, J. J. M.; Kooy, F.; Houghton, P.; Lall, N. Bioorg. Med. Chem. 2007, 15, 7638.

4. Mishra, B. B.; Kishore, N.; Tiwari, V. K.; Singh, D. D.; Tripathi, V. Fitoterapia 2010, 81, 104.

5. Mishra, B. B.; Singh, D. D.; Kishore, N.; Tiwari, V. K.; Tripathi, V. Phytochemistry 2010, 71, 230.

6. Lien, J.-C.; Huang, L.-J.; Teng, C.-M.; Wang, J.-P.; Kuo, S.-C. Chem. Pharm. Bull. 2002, 50, 672.

7. Yuk, D.-Y.; Ryu, C.-K.; Hong, J.-T.; Chung, K.-H.; Kang, W.-S.; Kim, Y.; Yoo, H.-S.; Lee, M.-K.; Lee, C.-K.; Yun, Y.-P. Biochem. Pharmacol. 2000, 60, 1001.

8. $\quad$ da Silva, A. J. M.; Buarque, C. D.; Brito, F. V.; Aurelian, L.; Macedo, L. F.; Malkas, L. H.; Hickey, R. J.; Lopes, D. V. S.; Noel, F.; Murakami, Y. L. B.; Silva, N. M. V.; Melo, P. A.; Caruso, R. R. B.; Castro, N. G.; Costa, P. R. R. Bioorg. Med. Chem. 2002, 10, 2731.

9. Huang, S.-T.; Kuo, H.-S.; Hsiao, C.-L.; Lin, Y.-L. Bioorg. Med. Chem. 2002, 10, 1947.

10. Tandon, V. K.; Chhor, R. B.; Singh, R. V.; Rai, S.; Yadav, D. B. Bioorg. Med. Chem. Lett. $2004,14,1079$.

11. Ravelo, A. G.; Estevez-Braun, A.; Chavez-Orellana, H.; Perez-Sacau, E.; Mesa-Siverio, D. Curr. Topics Med. Chem. 2004, 4, 241.

12. Kim, H. J.; Mun, J. Y.; Chun, Y. J.; Choi, K. H.; Ham, S. W.; Kim, M. Y. Arch. Pharmacal Res. 2003, $26,405$.

13. Richwien, A.; Wurm, G. Pharmazie 2004, 59, 163.

14. Wurm, G.; Schwandt, S. Pharmazie 2003, 58, 531.

15. Song, G.-Y.; Kim, Y.; You, Y.-J.; Cho, H.; Kim, S.-H.; Sok, D.-E.; Ahn, B.-Z. Arch. Pharm. Pharm. Med. Chem. 2000, $333,87$.

16. Babich, H.; Stern, A.; Munday, R. Toxicology Letters 1993, 69, 69.

17. O'Brien, P. Chem. Biol. Interact. 1991, 80, 1.

18. Verma, R. P. Anticancer Agents Med. Chem. 2006, 6, 489.

19. Eckhardt, S. Curr. Med. Chem. 2002, 2, 419.

20. Shukla, S.; Srivastava, R. S.; Shrivastava, S. K.; Sodhi, A.; Kumar, P. Asian Pac. J. Trop. Biomed. 2012, S, 1040.

21. Rajput, S.; Gardner, C. R.; Failes, T. W.; Arndt, G. M.; Black, D. C.; Kumar, N. Bioorg. Med. Chem. 2014, $22,105$.

22. Gillet, J. P.; Gottesman, M. M. Curr. Pharm. Biotechnol. 2011, 12, 686.

23. Duan, Z.; Li, X.; Huang, H.; Yuan, W.; Zheng, S. L.; Liu, X.; Zhang, Z.; Choy, E.; Harmon, D.; Mankin, H.; Hornicek, F. J. Med. Chem. 2012, 55, 3113.

24. Ali, I.; Wani, W.A.; Saleem, K.; Haque, A. Anticancer Agents Med. Chem. 2013, 13, 296.

25. Ali, I,; Wani, W.A.; Saleem, K.; Haque, A. Current Drug Ther. 2012, 7, 13.

26. Ali, I. Curr. Cancer Drug Targets 2011, 11, 130.

27. Ali, I., Rahis-ud-din; Saleem, K.; Aboul-Enein, H.Y.; Rather, A. Cancer Therapy 2011, 8, 6.

28. Van Wyk, B. E.; Van Oudtshoorn, B.; Gericke, N. 1997. Medicinal plants of South Africa. Briza Publications, Pretoria, South Africa.

29. Joubert, A.; van der Kooy, F.; Meyer, J. J. M.; Lall, N. Chromatographia 2006, 64, 399.

30. Nicoletti, I.; Migliorati, G.; Pagliacci, M. C.; Grignani, F.; Riccardi, C. J. Immunol. Methods 1991, $139,271$.

31. Peng, Y.; Kou, H.; Tsai, H.; Yang, Y.; Lin, Y. Bioorg. Med. Chem. 2006, 14, 263.

32. Koduru, S.; Grierson, D. S.; van de Venter, M.; Afolayan, A. J. Pharm. Biology 2007, 45, 613.

33. Qin, L. F.; Ng, I. O. L. Cancer Lett. 2002, 175, 27.

34. Sun, S. Y.; Hail, N.; Lotan, R. J. Natl. Cancer Inst. 2004, 96, 662.

35. Nishida, M.; Nasu, K.; Ueda, T.; Yuge, A.; Takai, N.; Narahara, H. Human Reporo. 2006, 21, 2850.

36. Nakagawa, H.; Tsuta, K.; Kiuchi, K.; Senzaki, H.; Tanaka, K.; Hioki, K.; Tsubura, A. Carcinogenesis 2001, $22,891$.

37. Copeland, Jr. R. L.; Das, J. R.; Bakare, O.; Enwerem, N. M.; Berhe, S.; Hillaire, K.; Douglas, W. D.; Beyene, D.; Kassim, K.; Kanaan, Y. M. Anticancer Res. 2007, 27, 1537.

38. Warrington, R. C.; Norum, J. N.; Hilchey, J. L.; Watt, C.; Fang, W. D. Prog. Neuropsycho. Pharmacol. Biol. Psychiatry 2003, 27, 231. 


\section{Synthesis of 1,4-naphthoquinones derivatives}

The synthesis of 7-MJ (1) and its derivatives 2-19 (Table 1) has been done by same method as previously synthesized in our laboratory. ${ }^{3}$

5.1. General procedure for the preparation of 7-methyl-juglone (1) and 5-Hydroxy-6-methyl-1,4naphthoquinones (6). A solution of appropriate 8-chloro-1,4-naphthoquinones (200 $\mathrm{mg}, 0.90 \mathrm{mmol})$ in THF (20 $\mathrm{ml})$ was added drop wise to a solution of $\mathrm{SnCl}_{2}(1.0 \mathrm{~g}, 51 \mathrm{mmol})$ in $4 \mathrm{M} \mathrm{HCl}(70 \mathrm{ml})$ and $\mathrm{THF}(20 \mathrm{ml})$ at $60{ }^{\circ} \mathrm{C}$ and stirred for $3 \mathrm{~h}$. It was then cooled and filtered into a solution of $\mathrm{FeCl}_{3}$. The resulting precipitate was filtered and dried to afford the required products.

5.1.1. 5-Hydroxy-7-methyl-1,4-naphthoquinone (1). The compound was obtained as orange needles from $\mathrm{CHCl3}$, yield $65 \%$, mp $125{ }^{\circ} \mathrm{C}\left(\mathrm{lit} .126{ }^{\circ} \mathrm{C}\right)$; $\mathrm{IR}\left(\mathrm{KBr}, \mathrm{cm}^{-1}\right)$ : $1670,1645(\mathrm{C}=\mathrm{O})$; $\delta_{\mathrm{H}}\left(\mathrm{CDCl}_{3}, 200 \mathrm{MHz}\right) ; 11.84(1 \mathrm{H}, \mathrm{s}, 5-\mathrm{OH}), 7.42(1 \mathrm{H}, \mathrm{s}, \mathrm{H}-8), 7.06(1 \mathrm{H}, \mathrm{s}, \mathrm{H}-6), 6.89(2 \mathrm{H}$, s, H-2, H-3), $2.41\left(3 \mathrm{H}, \mathrm{s}, \mathrm{CH}_{3}\right)$; found: (EI) $188.0475, \mathrm{C}_{11} \mathrm{H}_{8} \mathrm{O}_{3}$ requires 188.0473.

5.1.2. 5-Hydroxy-6-methyl-1,4-naphthoquinone (6). The compound was obtained as dark orange needles from $\mathrm{CHCl}_{3}$, yield $60 \%, \mathrm{mp} 104{ }^{\circ} \mathrm{C}\left(\mathrm{lit} .108{ }^{\circ} \mathrm{C}\right)$; IR $\left(\mathrm{KBr}, \mathrm{cm}^{-1}\right): 1663,1655$ $(\mathrm{C}=\mathrm{O}) ; \delta_{\mathrm{H}}\left(\mathrm{CDCl}_{3}, 200 \mathrm{MHz}\right) ; 13.0(1 \mathrm{H}, \mathrm{s}, 5-\mathrm{OH}), 7.48(1 \mathrm{H}, \mathrm{s}, \mathrm{H}-7), 7.23(1 \mathrm{H}, \mathrm{s}, \mathrm{H}-8), 6.89$ $(2 \mathrm{H}, \mathrm{s}, \mathrm{H}-2, \mathrm{H}-3), 2.32\left(3 \mathrm{H}, \mathrm{s}, \mathrm{CH}_{3}\right) . \delta_{\mathrm{C}}\left(\mathrm{CDCl}_{3}, 50 \mathrm{MHz}\right) ; 15.81\left(\mathrm{CH}_{3}\right), 115.00,124.64$, 126.04, 136.60, 136.76, 140.24, 140.94, $160.22(\mathrm{C}-5), 182.62(\mathrm{C}=\mathrm{O}), 190.10(\mathrm{C}=\mathrm{O})$; found: (EI) $188.0462, \mathrm{C}_{11} \mathrm{H}_{8} \mathrm{O}_{3}$ requires 188.0473.

5.2. General procedure for the preparation of 8-halogen derivatives (2-5). A mixture of anhydrous $\mathrm{AlCl} 3$ $(40 \mathrm{~g}, 300 \mathrm{mmol})$ and $\mathrm{NaCl}(8 \mathrm{~g}, 137 \mathrm{mmol})$ were heated to $180{ }^{\circ} \mathrm{C}$. A mixture of appropriate 4-halo-3-methyl phenol $(10.7 \mathrm{mmol})$ or 4-halo-2-methyl phenol and maleic anhydride $(4 \mathrm{~g}, 40.8 \mathrm{mmol})$ was added to the above melt with vigorous stirring for $2 \mathrm{~min}$, and then poured into a mixture of ice and $12 \mathrm{M} \mathrm{HCl}$. The mixture was kept for $30 \mathrm{~min}$, and the precipitate was filtered and dried at room temperature overnight. The residue obtained was powdered and extracted with n-hexane with vigorous stirring at $50{ }^{\circ} \mathrm{C}$. The extract was concentrated under reduced pressure and crystallized from chloroform to afford the corresponding halogenated products.

1.2.1. 8-Bromo-5-hydroxy-7-methyl-1,4-naphthoquinone (3). The compound was obtained as dark red needles from $\mathrm{CHCl}_{3}$, yield $27 \% \mathrm{mp} 154{ }^{\circ} \mathrm{C}$; IR $\left(\mathrm{KBr}, \mathrm{cm}^{-1}\right): 1663,1642(\mathrm{C}=\mathrm{O}) ; \delta_{\mathrm{H}}\left(\mathrm{CDCl}_{3}, 200 \mathrm{MHz}\right) ; 12.54(1 \mathrm{H}, \mathrm{s}, 5-$ $\mathrm{OH}), 7.18(1 \mathrm{H}, \mathrm{s}, \mathrm{H}-6), 6.88(2 \mathrm{H}, \mathrm{s}, \mathrm{H}-2, \mathrm{H}-3), 2.47\left(3 \mathrm{H}, \mathrm{s}, \mathrm{CH}_{3}\right) ; \delta_{\mathrm{C}}\left(\mathrm{CDCl}_{3}, 50 \mathrm{MHz}\right) ; 189.50(\mathrm{C}-4), 183.21(\mathrm{C}-$ 1), 160.54 (C-5), 148.99 (C-8), 140.84 (C-2), 140.69 (C-3), 136.61 (C-7), 136.52 (C-9), 125.88 (C-6), 114.53 (C10), 21.89 (C-11); found: (EI) 265.9574, $\mathrm{C}_{11} \mathrm{H}_{7} \mathrm{BrO}_{3}$ requires 265.9579.

1.2.2. 8-Fluoro-5-hydroxy-7-methyl-1,4-naphthoquinone (4). The compound was obtained as dark orange needles from $\mathrm{CHCl} 3$, yield $25 \%, \mathrm{mp} 150{ }^{\circ} \mathrm{C}$; IR $\left(\mathrm{KBr}, \mathrm{cm}^{-1}\right): 1663,1642(\mathrm{C}=\mathrm{O}) ; \delta_{\mathrm{H}}\left(\mathrm{CDCl}_{3}, 200 \mathrm{MHz}\right) ; 12.59$ $(1 \mathrm{H}, \mathrm{s}, 5-\mathrm{OH}), 7.31(1 \mathrm{H}, \mathrm{s}, \mathrm{H}-6), 6.95(2 \mathrm{H}, \mathrm{s}, \mathrm{H}-2, \mathrm{H}-3), 2.53(3 \mathrm{H}, \mathrm{s}, \mathrm{CH} 3) ; \delta_{\mathrm{C}}\left(\mathrm{CDCl}_{3}, 50 \mathrm{MHz}\right): 189.51(\mathrm{C}-4)$, 183.22 (C-1), 160.54 (C-5), 148.99 (C-8), 140.85 (C-2), 140.36 (C-3), 137.61 (C-7), 136.62 (C-9), 125.89 (C-6), 114.53 (C-10), 21.89 (C-11); found: (EI) 206.0372, $\mathrm{C}_{11} \mathrm{H}_{7} \mathrm{FO}_{3}$ requires 206.0379.

5.3. General procedure for the preparation of 5 -alkoxy-derivatives (7-8 and 11-14). A mixture of appropriate naphthoquinone $(0.45 \mathrm{mmol}), \mathrm{Ag}_{2} \mathrm{O}(130 \mathrm{mg}, 0.56 \mathrm{mmol})$ and either methyl- or ethyl-iodide (48.19 mmol) in acetone $(3 \mathrm{ml})$ was refluxed at $60{ }^{\circ} \mathrm{C}$ for $2-4 \mathrm{~h}$. The reaction mixture was then filtered and concentrated under reduced pressure. It was purified by silica gel chromatography (eluted with a gradient of ethyl acetate in hexane) and then crystallised (from hexane/ chloroform) to afford the respective 5-methoxy- and 5-ethoxy-1,4naphthoquinone derivatives.

5.3.1. 8-Chloro-5-methoxy-7-methyl-1,4-naphthoquinone (7). The compound was prepared from 3 as a yellow amorphous powder; yield $70 \%, \mathrm{mp} 142{ }^{\circ} \mathrm{C}$; IR $\left(\mathrm{KBr}, \mathrm{cm}^{-1}\right): 1657(\mathrm{C}=\mathrm{O})$; $\delta_{\mathrm{H}}\left(\mathrm{CDCl}_{3}, 200 \mathrm{MHz}\right) ; 7.28(1 \mathrm{H}, \mathrm{s}, \mathrm{H}-6), 6.85(1 \mathrm{H}, \mathrm{s}, \mathrm{H}-3), 6.83(1 \mathrm{H}, \mathrm{s}, \mathrm{H}-2), 4.02(3 \mathrm{H}, \mathrm{s}$, $\left.\mathrm{OCH}_{3}\right), 2.56\left(3 \mathrm{H}, \mathrm{s}, \mathrm{CH}_{3}\right)$; found: (EI) $236.0252, \mathrm{C}_{12} \mathrm{H}_{9} \mathrm{ClO}_{3}$ requires 236.0240 .

5.3.2. 8-Chloro-5-ethoxy-7-methyl-1,4-naphthoquinone (8). The compound was prepared from 3 as a brown semi-solid; yield $70 \%$, IR $\left(\mathrm{KBr}, \mathrm{cm}^{-1}\right): 1658(\mathrm{C}=\mathrm{O}) ; \delta_{\mathrm{H}}\left(\mathrm{CDCl}_{3}, 200\right.$ $\mathrm{MHz}) ; 7.31(1 \mathrm{H}, \mathrm{s}, \mathrm{H}-6), 6.85(1 \mathrm{H}, \mathrm{s}, \mathrm{H}-3), 6.84(1 \mathrm{H}, \mathrm{s}, \mathrm{H}-2), 4.24\left(2 \mathrm{H}, \mathrm{q}, \mathrm{J}, 7.5, \mathrm{OCH}_{2}\right)$, $2.56\left(3 \mathrm{H}, \mathrm{s}, 7-\mathrm{CH}_{3}\right), 1.62\left(3 \mathrm{H}, \mathrm{t}, \mathrm{J} 7.5, \mathrm{CH}_{2} \mathrm{CH}_{3}\right) ; \delta_{\mathrm{C}}\left(\mathrm{CDCl}_{3}, 50 \mathrm{MHz}\right) ; 185.58(\mathrm{C}=\mathrm{O})$, $183.92(\mathrm{C}=\mathrm{O}), 159.18(\mathrm{C}-5), 146.17,140.95,140.94,135.88,133.70,119.82,119.43,65.02$ $\left(\mathrm{OCH}_{2}\right), 22.19\left(\mathrm{CH}_{3}\right), 14.61\left(\mathrm{CH}_{3}\right)$; found: (EI) 250.0137, $\mathrm{C}_{13} \mathrm{H}_{11} \mathrm{ClO}_{3}$ requires 250.0397.

5.3.3. 5-Ethoxy-7-methyl-1,4-naphthoquinone (12). The compound was prepared from 6 as a brown semisolid; yield 98\%, IR $\left(\mathrm{KBr}, \mathrm{cm}^{-1}\right): 1642(\mathrm{C}=\mathrm{O}) ; \delta_{\mathrm{H}}\left(\mathrm{CDCl}_{3}, 200 \mathrm{MHz}\right) ; 7.52(1 \mathrm{H}$, $\mathrm{s}, \mathrm{H}-6), 7.07(1 \mathrm{H}, \mathrm{s}, \mathrm{H}-8), 6.81(2 \mathrm{H}, \mathrm{s}, \mathrm{H}-2, \mathrm{H}-3), 4.20\left(2 \mathrm{H}, \mathrm{q}, \mathrm{J} 7.5, \mathrm{OCH}_{2}\right), 2.45(3 \mathrm{H}, \mathrm{s}$, $\left.\mathrm{CH}_{3}\right), 1.53\left(3 \mathrm{H}, \mathrm{t}, \mathrm{J} 7.5, \mathrm{CH}_{2} \mathrm{CH}_{3}\right)$; found: (EI) $216.0577, \mathrm{C}_{13} \mathrm{H}_{12} \mathrm{O}_{3}$ requires 216.0786. 
5.3.4. 8-Chloro-5-methoxy-6-methyl-1,4-naphthoquinone (13). The compound was prepared from 5 as a brown needles, yield 75\%; IR $\left(\mathrm{KBr}, \mathrm{cm}^{-1}\right): 1658,(\mathrm{C}=\mathrm{O}) ; \delta_{\mathrm{H}}\left(\mathrm{CDCl}_{3}\right.$, $200 \mathrm{MHz}) ; 7.58(1 \mathrm{H}, \mathrm{s}, \mathrm{H}-6), 6.85(1 \mathrm{H}, \mathrm{s}, \mathrm{H}-3), 6.83(1 \mathrm{H}, \mathrm{s}, \mathrm{H}-2), 3.85\left(3 \mathrm{H}, \mathrm{s}, \mathrm{OCH}_{3}\right), 2.38$ $\left(3 \mathrm{H}, \mathrm{s}, \mathrm{CH}_{3}\right) ; \delta_{\mathrm{C}}\left(\mathrm{CDCl}_{3}, 50 \mathrm{MHz}\right) ; 188.27(\mathrm{C}=\mathrm{O}), 183.23(\mathrm{C}=\mathrm{O}), 159.58(\mathrm{C}-5), 142.85$, $140.19,133.44,132.54,129.30,126.12,118.02,21.08(\mathrm{CH} 3), 16.13\left(\mathrm{CH}_{3}\right)$; found: (EI) $236.0453, \mathrm{C}_{12} \mathrm{H}_{9} \mathrm{ClO}_{3}$ requires 236.0240 .

5.3.5. 8-Chloro-5-ethoxy-6-methyl-1,4-naphthoquinone (14). Was prepared from 5 as a brown semi-solid; yield 72\%, IR $\left(\mathrm{KBr}, \mathrm{cm}^{-1}\right): 1655(\mathrm{C}=\mathrm{O}) ; \delta_{\mathrm{H}}\left(\mathrm{CDCl}_{3}, 200 \mathrm{MHz}\right) ; 7.55(1 \mathrm{H}$, s, H-6), $6.82(1 \mathrm{H}, \mathrm{s}, \mathrm{H}-3), 6.80(1 \mathrm{H}, \mathrm{s}, \mathrm{H}-2), 3.94\left(2 \mathrm{H}, \mathrm{q}, \mathrm{J} 7.5, \mathrm{OCH}_{2}\right), 2.34\left(3 \mathrm{H}, \mathrm{s}, \mathrm{CH}_{3}\right)$, $1.47\left(3 \mathrm{H}, \mathrm{t}, \mathrm{J} 7.5, \mathrm{CH}_{2} \mathrm{CH}_{3}\right) ; \delta_{\mathrm{C}}\left(\mathrm{CDCl}_{3}, 50 \mathrm{MHz}\right) ; 183.90(\mathrm{C}=\mathrm{O}), 183.58(\mathrm{C}=\mathrm{O}), 156.94(\mathrm{C}-$ $5), 141.74,139.26,138.33,138.20,129.29,126.29,114.30,70.34\left(\mathrm{OCH}_{2}\right), 16.57\left(\mathrm{CH}_{3}\right)$, $14.07\left(\mathrm{CH}_{3}\right)$; found: (EI) $250.0564, \mathrm{C}_{13} \mathrm{H}_{11} \mathrm{ClO}_{3}$ requires 250.0397.

5.4. General procedure for the preparation of 5-acetoxy derivatives (9-10 and 15). A mixture of appropriate naphthoquinone $(0.45 \mathrm{mmol})$, anhydrous sodium acetate $(40 \mathrm{mg}, 0.49 \mathrm{mmol})$ and acetic anhydride $(2 \mathrm{ml}, 19.59$ mmol) was heated under reflux for $3 \mathrm{~h}$. The reaction mixture was poured into hot water. It was allowed to cool and extracted with $\mathrm{CHCl} 3$, dried $\left(\mathrm{MgSO}_{4}\right)$, concentrated and crystallised from chloroform-hexane to yield the corresponding 5-acetoxy derivatives.

5.4.1. 5-Acetoxy-8-chloro-6-methyl-1,4-naphthoquinone (15). The compound was prepared from 5 as a greyish amorphous powder, yield $74 \%, \mathrm{mp} 230{ }^{\circ} \mathrm{C}$; IR $\left(\mathrm{KBr}, \mathrm{cm}^{-1}\right)$ : 1770 (aryl acetate $\mathrm{C}=\mathrm{O}), 1660$ (quinone $\mathrm{C}=\mathrm{O}) ; \delta_{\mathrm{H}}\left(\mathrm{CDCl}_{3}, 200 \mathrm{MHz}\right) ; 7.63(1 \mathrm{H}, \mathrm{s}, \mathrm{H}-6), 6.73(1 \mathrm{H}, \mathrm{d}, \mathrm{J}$ $10.0, \mathrm{H}-2), 6.90(1 \mathrm{H}, \mathrm{d}, \mathrm{J} 10.0, \mathrm{H}-3), 2.44(3 \mathrm{H}, \mathrm{s}, \mathrm{CH} 3), 2.27\left(3 \mathrm{H}, \mathrm{s}, \mathrm{CH}_{3}\right) ; \delta_{\mathrm{C}}\left(\mathrm{CDCl}_{3}, 50\right.$ $\mathrm{MHz}) ; 190.97(\mathrm{C}=\mathrm{O}), 182.28(\mathrm{C}=\mathrm{O}), 168.89(\mathrm{C}=\mathrm{O}), 159.54(\mathrm{C}-5), 140.12,139.25,138.80$, 137.88, 131.85, 130.88, 128.80, $20.82\left(\mathrm{CH}_{3}\right), 16.14\left(\mathrm{CH}_{3}\right)$; found: (EI) 264.0182, $\mathrm{C}_{13} \mathrm{H}_{9} \mathrm{ClO}_{4}$ requires 264.0189.

5.5. General Procedure for the preparation of 1,2,4,5-tetra-acetoxy derivatives (16-18). A mixture of appropriate naphthoquinone $(100 \mathrm{mg})$, acetic anhydride $(3 \mathrm{ml}, 29.39 \mathrm{mmol})$ and conc. $\mathrm{H}_{2} \mathrm{SO}_{4}(0.1 \mathrm{ml})$ was kept overnight then poured into ice. The reaction mixture was extracted with $\mathrm{CHCl}_{3}$, dried $\left(\mathrm{MgSO}_{4}\right)$ and then concentrated under reduced pressure. The residue obtained was crystallised from chloroform-hexane to give the respective pentaacetate derivatives.

5.5.1. 8-Chloro-7-methylnaphthalene-1,2,4,5-tetra-O-acetate (16). The compound was prepared from 3 as a brown semi-solid; yield $70 \%, \mathrm{mp} 159{ }^{\circ} \mathrm{C}$, IR $\left(\mathrm{KBr}, \mathrm{cm}^{-1}\right): 1778(\mathrm{C}=\mathrm{O})$; $\delta_{\mathrm{H}}\left(\mathrm{CDCl}_{3}, 200 \mathrm{MHz}\right) ; 7.16(1 \mathrm{H}, \mathrm{s} \mathrm{H}-6), 7.06(1 \mathrm{H}, \mathrm{s}, \mathrm{H}-3), 2.48(3 \mathrm{H}, \mathrm{s}, \mathrm{OAc}) 2.45(3 \mathrm{H}, \mathrm{s}$, $\mathrm{OAc}), 2.38(3 \mathrm{H}, \mathrm{s}, \mathrm{OAc}), 2.33(3 \mathrm{H}, \mathrm{s}, \mathrm{OAc}), 2.25\left(\mathrm{ArCH}_{3}\right) ; \delta_{\mathrm{C}}\left(\mathrm{CDCl}_{3}, 50 \mathrm{MHz}\right) ; 169.30$, $168.67,168.39,167.43(4 \cdot \mathrm{C}=\mathrm{O}), 145.81,143.71,139.60,137.77,136.70,124.72,123.90$, $118.58,116.93,21.62,21.52,21.04,20.62,20.52\left(5 . \mathrm{CH}_{3}\right)$; found: (EI) 408.0561, $\mathrm{C}_{19} \mathrm{H}_{12} \mathrm{ClO}_{8}$ requires 408.0612 .

5.5.2. 8-Chloro-6-methylnaphthalene-1,2,4,5-tetra-O-acetate (18). The compound was prepared from 5 as a brown solid; yield $70 \%, \mathrm{mp} 137{ }^{\circ} \mathrm{C}, \mathrm{IR}\left(\mathrm{KBr}, \mathrm{cm}^{-1}\right): 1772(\mathrm{C}=\mathrm{O}) ; \delta_{\mathrm{H}}$ $\left(\mathrm{CDCl}_{3}, 200 \mathrm{MHz}\right) ; 7.46(1 \mathrm{H}, \mathrm{s}, \mathrm{H}-6), 7.11(1 \mathrm{H}, \mathrm{s}, \mathrm{H}-3), 2.38(3 \mathrm{H}, \mathrm{s}, \mathrm{OAc}) 2.37(3 \mathrm{H}, \mathrm{s}$, $\mathrm{OAc}), 2.35(3 \mathrm{H}, \mathrm{s}, \mathrm{OAc}), 2.29(3 \mathrm{H}, \mathrm{s}, \mathrm{OAc}), 2.21\left(\mathrm{ArCH}_{3}\right) ; \delta_{\mathrm{C}}\left(\mathrm{CDCl}_{3}, 50 \mathrm{MHz}\right) ; 168.81$, $168.32,168.30,167.67$ (4 C=O), 142.87, 140.61, 133.47, 132.54, 129.29, 126.12, 122.01, $118.02,117.53,21.06,20.95,20.74,20.64,16.64\left(5-\mathrm{CH}_{3}\right)$; found: (EI) 408.0631, $\mathrm{C}_{19} \mathrm{H}_{12} \mathrm{ClO}_{8}$ requires 408.0612 .

5.5.3. 2,5-Dihydroxy-7-methyl-1,4-naphthoquinone (19). A mixture of tetra-acetate 17 $(200 \mathrm{mg}, 0.52 \mathrm{mmol})$ in methanolic $\mathrm{HCl}(2 \mathrm{M}, 4 \mathrm{ml})$ was heated under reflux for $30 \mathrm{~min}$. The reaction mixture was extracted with ether and evaporated. The residue was purified by column chromatography using chloroform-methanol (95:5) as eluent to obtain the required compound. This was then recrystallized from chloroform to obtain 20 as orange plates (34 $\mathrm{mg}, 32 \%)$; $\mathrm{mp} 198{ }^{\circ} \mathrm{C}\left(1 \mathrm{it} .208-210{ }^{\circ} \mathrm{C}\right)$; IR $\left(\mathrm{KBr}, \mathrm{cm}^{-1}\right): 1640(\mathrm{C}=\mathrm{O}) ; \delta_{\mathrm{H}}\left(\mathrm{CDCl}_{3}, 200 \mathrm{MHz}\right)$; $11.69(1 \mathrm{H}, \mathrm{s}, 5-\mathrm{OH}), 7.42(1 \mathrm{H}, \mathrm{s}, \mathrm{H}-8), 7.01(1 \mathrm{H}, \mathrm{s}, \mathrm{H}-6), 6.08(1 \mathrm{H}, \mathrm{s}, \mathrm{H}-3), 2.40(3 \mathrm{H}, \mathrm{s}$, $\mathrm{CH}_{3}$ ); found: (EI) $204.0425, \mathrm{C}_{11} \mathrm{H}_{8} \mathrm{O}_{4}$ requires 204.0423 . 